\title{
The Correlation Between Students' Attitude And Motivation Towards Students' Study Of Result On Mathematics Class IV SDN Pasanggrahan II Kecamatan Solear: Penelitian Kuantitatif Korelasional Pada Mata Pelajaran Matematika SDN Pasanggrahan II Kecamatan Solear
}

\author{
Mahdatul Nufus, Sholeh Hidayat dan Juhana \\ Program Pascasarjana, Universitas Terbuka, Indonesia \\ Email korespondensi: mahdatulnupus.nupus@gmail.com/ sholeh.hidayat@untirta.ac.id/ \\ juhana@ecampus.ut.ac.id
}

\begin{abstract}
ABSTRAK
Tujuan Penelitian adalah untuk menganalisis hubungan sikap siswa terhadap mata pelajaran matematika pada siswa kelas IV, menganalisis hubungan motivasi dengan hasil belajar matematika pada siswa kelas IV, dan menganalisis hubungan sikap dan motivasi belajar siswa dengan hasil belajar matematika siswa kelas IV SDN Pasanggrahan II. Sampel yang digunakan adalah 35 orang, yaitu kelas IV C. Variabel penelitian ini adalah bebas, yaitu Sikap Siswa ( $X_{1}$ ) dan Motivasi Belajar $\left(\mathrm{X}_{2}\right)$, sedangkan variabel terikatnya adalah hasil belajar matematika (Y). Pengukuran variabel dengan menggunakan skala likert untuk sikap dan motivasi serta tes PTS untuk hasil belajar matematika siswa. Hasil uji coba Reliabilitas untuk sikap 0,896, Reliabilitas untuk motivasi adalah 0,856, dan Reliabilitas untuk hasil belajar matematika diperoleh nilai sebesar 0,861. Hasil penelitian menunjukkan bahwa (1) bahwa korelasi sikap terhadap hasil belajar matematika menunjukkan angka 0,560 , artinya terdapat hubungan yang positif antara variable sikap belajar terhadap hasil belajar matematika, (2) korelasi motivasi belajar terhadap hasil belajar matematika menunjukkan angka (-) 0,138. Artinya, hubungan antara motivasi belajar siswa terhadap hasil belajar matematika siswa adalah "Sangat Rendah". Sementara tanda minus pada angka korelasi menunjukkan bahwa korelasi berhubungan terbalik artinya bila nilai motivasi meningkat maka nilai hasil belajar matematika akan menurun begitu pula sebaliknya. Dari tabel ANOVA kita dapatkan $F_{\text {Hitung }}=3,929>F_{\text {Tabel }}$ $=3,340$, maka $\mathrm{H}_{0}$ ditolak dan menerima Ha yang artinya variable sikap belajar dan motivasi belajar siswa secara simultan berpengaruh terhadap hasil belajar siswa.
\end{abstract}

Kata Kunci: Sikap, Motivasi, Hasil Belajar Matematika Siswa

\begin{abstract}
The research objectives were to analyze the relationship between students' attitudes towards mathematics in grade IV students, to analyze the relationship between motivation and mathematics learning outcomes in fourth grade students, and to analyze the relationship between students' attitudes and learning motivation and fourth grade students' mathematics learning outcomes at SDN Pasanggrahan II. The sample used was 35 people, namely class IV C. The variables of this study were independent, namely Student Attitude (X1) and Learning Motivation (X2), while the dependent variable was the result of learning mathematics (Y). Measurements of variables are using a Likert scale for attitudes and motivation and PTS tests for students' mathematics learning outcomes. The test results Reliability for attitudes is 0.896 , Reliability for motivation is 0.856 , and Reliability for mathematics learning outcomes is obtained by a value of 0.861 . The results showed that (1) that the correlation of attitudes towards mathematics learning outcomes showed the number 0.560 , meaning that there was a positive relationship between the variables of learning attitudes towards mathematics learning
\end{abstract}


outcomes, (2) the correlation between learning motivation and mathematics learning outcomes showed the number (-) 0.138 . That is, the relationship between students' learning motivation to students' mathematics learning outcomes is "Very Low". While the minus sign in the correlation number indicates that the correlation is inversely related, meaning that if the motivation value increases, the value of learning mathematics outcomes will decrease and vice versa. From the ANOVA table we get F Count $=3.929>$ FTable $=3.340$, then H0 is rejected and $\mathrm{Ha}$ is accepted, which means that the variables of student learning attitudes and learning motivation simultaneously affect student learning outcomes.

Keywords: Attitude, Motivation, Student Mathematics Learning Outcomes

\section{PENDAHULUAN}

Banyak siswa mulai dari SD, SMP maupun SMA beranggapan mata pelajaran matematika sebagai pelajaran yang sulit karena beberapa faktor yang ada, baik faktor dari siswa, guru maupun lingkungan. Kurangnya kemampuan guru dalam penguasaan kelas, model pembelajaran yang monoton sehingga membuat siswa merasa bosan dan kurang memperhatikan pelajaran yang disampaikan, hal tersebut yang membuat banyak siswa kurang tertarik dengan mata pelajaran matematika.

Dalam hubungan ini, Djaali (2012: 114) menyatakan bahwa hubungan tidak baik dengan guru dapat menghalangi prestasi belajar yang tinggi. Sikap belajar siswa bukan saja sikap yang ditunjukan kepada guru, melainkan juga kepada tujuan yang akan dicapai. Materi pelajaran, tugas, dan lain-lain. Sikap, menurut Slameto (2015: 188) merupakan suatu yang dipelajari, dan sikap menentukan bagaimana individu bereaksi terhadap situasi serta menentukan apa yang dicari individu dalam kehidupan. Sikap selalu berkenaan dengan suatu objek, dan sikap terhadap objek ini disertai dengan perasaan positif dan negatif. Penelitian yang dilakukan oleh Fatimaturrohmah (2010), yang menunjukkan bahwa ada hubungan yang positif dan signifikan antara sikap siswa terhadap pelajaran matematika dengan prestasi belajar matematika siswa. Hal ini sejalan dengan penelitian yang dilakukan oleh Winantiti (2011), hasil penelitian menunjukan bahwa diperoleh nilai dengan tingkat signifikan $1 \%$ menunjukan adanya hubungan yang positif antara sikap siswa terhadap mata pelajaran matematika dengan prestasi belajar matematika.

Sikap yang baik itu dapat terlihat dengan jelas dengan adanya motivasi yang tinggi dari siswa. Motivasi rnerupakan dorongan untuk mernenuhi kebutuhan-kebutuhan tertentu dari seseorang, sedangkan motivasi belajar merupakan dorongan bagi seseorang untuk berkerja sebaik-baiknya agar mencapai hasil yang terbaik. Motivasi merupakan dorongan untuk melakukan sesuatu yang berasal dari dalam diri dan dari dorongan datangnya dari luar. Seseorang yang mempunyai motivasi belajar akan belajar dengan sungguh-sungguh dan penuh semangat. Sebab itu, motivasi belajar sangat penting di dalam proses pembelajaran guna menghadapi masa depan yang penuh tantangan dan untuk mencapai cita-cita.

Slameto (2015: 54) mengatakan motivasi belajar merupakan salah satu faktor yang mempengaruhi hasil belajar. Motivasi belajar diperlukan untuk menumbuhkan minat terhadap pelajaran, sehingga siswa terdorong untuk belajar.Kadang siswa dan guru kurang memperhatikan hal-hal yang bisa memotivasi siswa dalam belajar.

Fita Nur Arifah (2016: 6) mengatakan bahwa seseorang yang tidak mempunyai motivasi belajar, tidak akan mungkin melakukan aktivitas belajar dan hasil belajarnya akan rendah. Sebaliknya, seseorang yang mempunyai motivasi belajar, akan dengan baik melakukan 
aktivitas belajar dan memiliki hasil belajar yang lebih baik. Hal ini menunjukkan seorang siswa yang cerdas, apabila memiliki motivasi belajar yang rendah maka dia tidak akan mencapai hasil belajar yang baik. Senada dengan penelitian yang dilakukan Rindra Listrianto (2017: 3), dalam skripsinya yang berjudul Hubungan Motivasi Belajar Dengan Hasil Belajar Matematika Siswa Kelas IV MIN 8 Bandar Lampung Tahun Ajaran 2016/2017. Hasil analisis dengan korelasi product moment menunjukkan bahwa terdapat hubungan positif dan signifikan antara motivasi belajar dengan hasil belajar matematika siswa kelas IV MIN 8 Bandar Lampung tahun ajaran 2016/2017. Hal ini dibuktikan dari besarnya nilai rhitung sebesar 0,871. Jika nilai rhitung dibandingkan dengan nilai rtabel sebesar 0,333 pada taraf signifikansi 5\% dapat ditarik kesimpulan> begitu juga dengan nilai signifikansi sebesar 0,000<0,05, dengan demikian Ha diterima dan Ho ditolak artinya terdapat hubungan positif dan signifikan antara motivasi belajar dengan hasil matematika siswa.

Dengan demikian dapat diduga bahwa siswa yang rnemiliki motivasi belajar akan memiliki sikap belajar yang baik pula. Sebaliknya, jika terjadi pada siswa yang memiliki motivasi rendah, mereka menampakkan sikap enggan, malas, cuek, cepat bosan dan berusaha rnenghindar dari kegiatan belajar, yang akhirnya akan berimplikasi terhadap hasil belajar matematika yang kurang memuaskan.

Hasil belajar dapat tercapai apabila siswa sudah memahami dan mengerti tujuan yang hendak di capai dengan di iringi dengan perilaku sikap dan motivasi yang baik pula. Hasil belajar didapatkan setelah siswa mengikuti pembelajaran, seberapa tinggi tingkat keberhasilan pembelajaran ditentukan dari sikap dan motivasi yang dimiliki siswa ketika mengikuti pembelajaran. Dari penjelasan yang telah penulis ungkapkan serta fakta dalam pembelajaran matematika serta masalah sikap dan motivasi siswa yang disampaikan dalam uraian di atas, maka penulis tertarik melakukan penelitian yang berkenaan dengan hubungan sikap dan motivasi belajar siswa dengan hasil belajar matematika pada siswa kelas IV SDN Pasanggrahan II Kecamatan Solear.

Berdasarkan uraian di atas rumusan masalah dalam penelitian ini adalah: Apakah terdapat hubungan sikap siswa dengan hasil belajar matematika pada siswa kelas IV SDN Pasanggrahan II? Apakah terdapat hubungan motivasi belajar dengan hasil belajar matematika pada siswa kelas IV SDN Pasanggrahan II? Apakah terdapat hubungan sikap dan motivasi belajar siswa secara bersama-sama dengan hasil belajar matematika pada siswa kelas IV SDN Pasanggrahan II?

\section{METODE}

Penelitian ini menggunakan penelitian kuantitatif, dengan pendekatan kuantitatif korelasional dan teknik penelitian berupa kuesioner dan soal tes. Untuk mendapatkan data primer di lapangan digunakan instrument yang disusun berdasarkan indikator-indikator yang ada dalam variabel penelitian. Data primer yang dibutuhkan adalah mengenai hubungan antara sikap siswa dan motivasi belajar siswa terhadap mata pelajaran matematika.

Populasi dalam penelitian ini adalah seluruh siswa kelas IV SDN Pasanggrahan II Kecamatan Solear Kabupaten Tangerang. Gambaran komposisi seluruh siswa kelas IV SDN Pasanggrahan II Kecamatan Solear. Yang terdiri dari 101 siswa yang terbagi dalam tiga rombongan belajar, yaitu kelas IV A, IV B dan IV C. Dari populasi tersebut peneliti menggunakan teknik pengambilan anggota sampel dari populasi dilakukan secara purposive technique sampling, yaitu kelas IV C. Hal ini dilakukan dengan beberapa pertimbangan, 
pertama, peneliti adalah guru kelas yang mengajar di kelas tersebut. Kedua, sistem pembelajaran online atau daring agak menyulitkan peneliti untuk mengatur waktu atau membagi jam untuk kelas IV A maupun B. Jadi jumlah sampelnya adalah sebanyak 35 orang.

Pada penelitian ini instrumen yang digunakan adalah kuesioner dan tes. Instrumen kuesioner digunakan untuk memperoleh informasi dari variabel bebas yaitu sikap siswa dan motivasi belajar instrumen soal tes untuk variabel terikat adalah hasil belajar matematika. Kuesioner penelitian terdiri dari 20 pernyataan untuk variabel sikap siswa, 20 pernyataan untuk motivasi belajar siswa dan 30 soal matematika materi menentukan Pecahan, Faktor dan Kelipatan dan Persekutuan Faktor Terbesar (FPB), Kelipatan Persekutuan Terkecil (KPK) dari dua bilangan berkaitan kehidupan sehari-hari. Angket pada penelitian ini adalah angket tertutup yaitu angket yang telah dilengkapi dengan pilihan jawaban sehingga responden dapat memberikan jawaban pada lembar jawaban yang telah disediakan.

Instrumen dalam penelitian ini diukur dengan menggunakan skala Likert. Siswa di minta untuk memberikan jawaban dengan memberi tanda $\left({ }^{3}\right)$ hanya pada satu pilihan jawaban yang telah tersedia. Terdapat empat pilihan jawaban yang telah di modifikasi, yaitu Selalu, Sering, Kadang-kadang, dan Tidak Pernah. Instrumen disusun berdasarkan indikator-indikator yang berkaitan dengan sikap, motivasi belajar dan mata pelajaran matematika.

Analisis korelasi digunakan untuk menguji hipotesis dalam penelitian ini. Koefisien korelasi digunakan untuk mengukur atau mengetahui hubungan antara X dan Y. Uji statistik yang digunakan dalam penelitian ini adalah korelasi Product Moment dari Karl Person. Harga koefisien korelasi yang diperoleh selanjutnya dikonsultasikan dengan rtabel pada taraf signifikansi $5 \%$. Korelasi dikatakan signifikan jika rhitung lebih besar dari rtabel pada taraf signifikansi $5 \%$.

\section{HASIL DAN PEMBAHASAN}

\section{Uji Validitas}

Uji validitas digunakan untuk mengukur sah atau tidaknya suatu kuesioner. Kuesioner dikatakan valid jika pertanyaan pada kuesioner mampu mengungkapkan sesuatu yang akan diukur oleh kuesioner tersebut. Metode yang digunakan untuk menilai validitas kuesioner tersebut adalah korelasi produk moment atau menggunakan bevariate pearson, dimana $\boldsymbol{R}_{\boldsymbol{h i t u n g}}$

\section{$>$ Rtabel maka Valid.}

Dari uji validitas terhadap variabel sikap belajar siswa yang deskripsikan dengan sebanyak 20 pertanyaan maka berdasarkan perbandingan antara $R_{\text {hitung }}$ dengan $R_{\text {tabel }}$ untuk masing-masing pertanyaan, kita dapatkan bahwa untuk pertanyaan no. 3 dan 17 dinyatakan "Tidak Valid", oleh karena itu maka tidak kita ikutkan untuk tahap analisa selanjutnya. Dari uji validitas terhadap variabel motivasi belajar siswa yang deskripsikan dengan sebanyak 20 pertanyaan maka berdasarkan perbandingan antara $\mathrm{R}_{\text {hitung }}$ dengan $\mathrm{R}_{\text {tabel }}$ untuk masing-masing pertanyaan, kita dapatkan bahwa untuk pertanyaan no. 10 dan 20 dinyatakan "Tidak Valid", oleh karena itu maka tidak kita ikutkan untuk tahap analisa selanjutnya. Dari uji validitas terhadap variabel hasil belajar siswa yang deskripsikan dengan sebanyak 30 pertanyaan maka berdasarkan perbandingan antara $\mathrm{R}_{\text {hitung }}$ dengan $\mathrm{R}_{\text {tabel }}$ untuk masing-masing pertanyaan, kita dapatkan bahwa untuk pertanyaan no. 14, 17, 23, 26 dan 30 dinyatakan "Tidak Valid", oleh karena itu maka tidak kita ikutkan untuk tahap analisa selanjutnya. 


\section{Uji Reliabilitas}

Uji reliabilitas adalah untuk mengukur suatu kuesioner yang merupakan indikator dari variabel atau konstruk. Suatu kuesioner dikatakan reliabel jika jawaban seseorang terhadap pernyataan adalah konsisten atau stabil dari waktu ke waktu. Adapun dasar pengambilan keputusan dalam uji realibilitas adalah sebagai berikut:

1) Jika nilai Cronbach's Alpha $>0,60$ maka kuesioner atau angket dinyatakan reliabel atau konsisten

2) Jika nilai Cronbach's Alpha $<0,60$ maka kuesioner atau angket dinyatakan reliabel atau konsisten

Tabel 2. Uji Realibilitas Sikap Belajar Siswa

Reliability Statistics

Cronbach's

\begin{tabular}{r|r} 
Alpha & N of Items \\
\hline .896 & 18 \\
\hline
\end{tabular}

Dari tabel tersebut di atas, maka untuk variabel sikap belajar dinyatakan reliabel atau konsisten hal tersebut ditunjukkan dengan Cronbach's Alpha 0,896 > 0,60, sehingga layak untuk di lakukan analisis selanjutnya.

Tabel 3. Uji Realibilitas Motivasi Belajar Siswa

Reliability Statistics

Cronbach's

Alpha N of Items

$.856 \quad 18$

Dari tabel tersebut di atas, maka untuk variabel motivasi belajar dinyatakan reliabel atau konsisten hal tersebut ditunjukkan dengan Cronbach's Alpha 0,856 > 0,60, sehingga layak untuk di lakukan analisis selanjutnya.

Tabel 4. Uji Realibilitas Hasil Belajar Matematika

\section{Reliability Statistics}

Cronbach's

\begin{tabular}{r|r} 
Alpha & N of Items \\
\hline .861 & 25 \\
\hline
\end{tabular}

Dari tabel tersebut di atas, maka untuk variabel hasil belajar dinyatakan reliabel atau konsisten hal tersebut ditunjukkan dengan Cronbach's Alpha 0,861 >0,60, sehingga layak untuk di lakukan analisis selanjutnya

\section{Sikap siswa dalam belajar matematika}

Setelah melakukan olah data dengan menggunakan SPSS (Statistical Package for the Social Sciences) versi 22, maka sikap siswa dapat digambarkan secara lengkap dibawah ini:

\begin{tabular}{|c|c|c|c|c|c|c|c|c|c|}
\hline \multicolumn{10}{|c|}{ Descriptive Statistics } \\
\hline & \multirow{2}{*}{$\begin{array}{c}\mathrm{N} \\
\text { Statistic }\end{array}$} & \multirow{2}{*}{$\begin{array}{l}\text { Minimum } \\
\text { Statistic }\end{array}$} & \multirow{2}{*}{$\begin{array}{l}\text { Maximum } \\
\text { Statistic }\end{array}$} & \multirow{2}{*}{$\begin{array}{l}\text { Mean } \\
\text { Statistic }\end{array}$} & \multirow{2}{*}{$\begin{array}{l}\text { Std. Deviation } \\
\text { Statistic }\end{array}$} & \multicolumn{2}{|c|}{ Skewness } & \multicolumn{2}{|c|}{ Kurtosis } \\
\hline & & & & & & Statistic & Std. Error & Statistic & Std. Error \\
\hline Total_Skp & 30 & 34.00 & 65.00 & 51.1667 & 9.59915 & -.270 & .427 & -1.317 & .833 \\
\hline Valid N (listwise) & 30 & & & & & & & & \\
\hline
\end{tabular}


Dari tabel di atas maka dapat dilihat bahwa nilai rata-rata sikap belajar siswa/i sebesar 51,17 dan untuk mengetahui tingkatan sikap siswa dalam belajar matematika dapat menggunakan kategori rentang dibawah ini:

Tabel 5. Pengolongan Sikap Siswa

\begin{tabular}{|l|l|}
\hline Kategori & Nilai \\
\hline Selau & $60-72$ \\
\hline Sering & $46-59$ \\
\hline Kadang-kadang & $32-45$ \\
\hline Tidak pernah & $18-31$ \\
\hline
\end{tabular}

Kemudian untuk mengeatahui apakah nilai total tersebut terdistribusi secara normal atau tidak maka bias kita lihat dari analisis Kurtosis dan Skewness. Berdasarkan hasil olah data maka didapatkan nilai analisis Kurtosis sebesar -1,317 sementara nilai analisis Skewness sebesar 0,270 . Rentang nilai yang digunakan oleh analisis Kurtosis dan juga Skewness adalah antara 2,00 sampai dengan 2,00 maka dikatakan nilai tersebut terdistribusi secara normal, sehingga dari ketentuan nilai tersebut maka dapat disimpulkan bahwa nilai total untuk sikap belajar siswa telah terdistribusi secara normal karena untuk Kurtosis sebesar -1,317> -2,00 dan nilai Skewness sebesar -0,270>-2,00.

\section{Motivasi belajar siswa dalam mempelajari matematika}

Setelah melakukan olah data dengan menggunakan SPSS (Statistical Package for the Social Sciences) versi 22, maka motivasi belajar siswa dapat digambarkan secara lengkap dibawah ini:

\begin{tabular}{|l|r|c|c|c|c|c|c|c|c|c|}
\hline \multicolumn{10}{|c|}{ Tabel 4.3: Deskripsi Statistik Motivasi Belajar Siswa } \\
\hline & \multicolumn{1}{|c|}{ N } & Minimum & Maximum & Mean & Std. Deviation & Variance & \multicolumn{2}{|c|}{ Skewness } & \multicolumn{2}{c|}{ Kurtosis } \\
\cline { 2 - 11 } & Statistic & Statistic & Statistic & Statistic & Statistic & Statistic & Statistic & Std. Error & Statistic & Std. Error \\
\hline $\begin{array}{l}\text { Total_Mtv } \\
\text { Valid N (listwise) }\end{array}$ & 30 & 46.00 & 72.00 & 59.5000 & 7.71362 & 59.500 & -.325 & .427 & -1.074 & .833 \\
\hline
\end{tabular}

Dari tabel di atas maka dapat dilihat bahwa jumlah siswa yang dijadikan sebagai sample adalah sebanyak 30 siswa. Untuk nilai total motivasi belajar siswa yang paling rendah adalah sebesar 46 dan yang paling tinggi adalah sebesar nilai total 72 . Untuk nilai motivasi belajar siswa memiliki nilai rata-rata sebesar 59,50 dan untuk mengetahui tingkatan motivasi siswa dalam belajar matematika dapat menggunakan kategori rentang dibawah ini:

Tabel 4:3 Penggolongan Motivasi siswa

\begin{tabular}{|l|l|}
\hline Kategori & Nilai \\
\hline Selau & $60-72$ \\
\hline Sering & $46-59$ \\
\hline Kadang-kadang & $32-45$ \\
\hline Tidak pernah & $18-31$ \\
\hline
\end{tabular}

Kemudian untuk mengeatahui apakah nilai total tersebut terdistribusi secara normal atau tidak maka bisa kita lihat dari analisis Kurtosis dan Skewness. Berdasarkan hasil olah data maka didapatkan nilai analisis Kurtosis sebesar -1,074 sementara nilai analisis Skewness sebesar 0,325 . Rentang nilai yang digunakan oleh analisis Kurtosis dan juga Skewness adalah antara 2,00 sampai dengan 2,00 maka dikatakan nilai tersebut terdistribusi secara normal, sehingga dari ketentuan nilai tersebut maka dapat disimpulkan bahwa nilai total untuk sikap belajar 
siswa telah terdistribusi secara normal karena untuk Kurtosis sebesar $-1,074>-2,00$ dan nilai Skewness sebesar $-0,325>-2,00$.

\section{Hasil belajar matematika di sekolah}

Setelah melakukan olah data dengan menggunakan SPSS (Statistical Package for the Social Sciences) versi 22 , maka motivasi belajar siswa dapat digambarkan secara lengkap dibawah ini:

Tabel 4.5: Deskripsi Statistik Hasil Belajar Matematika

\begin{tabular}{|l|r|r|r|r|r|r|r|r|r|}
\hline & \multicolumn{1}{|c|}{$\mathrm{N}$} & \multicolumn{1}{|c|}{ Minimum } & Maximum & \multicolumn{1}{c|}{ Mean } & \multicolumn{2}{|c|}{ Std. Deviation } & \multicolumn{2}{|c|}{ Skewness } & \multicolumn{2}{|c|}{ Kurtosis } \\
\cline { 2 - 9 } & Statistic & Statistic & Statistic & Statistic & Statistic & Statistic & Std. Error & Statistic & Std. Error \\
\hline Total_Mtk & 30 & 14.00 & 25.00 & 20.1667 & 2.96047 & -.482 & .427 & -.405 & .833 \\
Valid N (listwise) & 30 & & & & & & & & \\
\hline
\end{tabular}

Dari tabel di atas maka dapat dilihat bahwa jumlah siswa yang dijadikan sebagai sample adalah sebanyak 30 siswa. Untuk nilai total hasil belajar matematika siswa yang paling rendah adalah sebesar 14 dan yang paling tinggi adalah sebesar nilai total 25. Untuk nilai hasil belajar matematika siswa memiliki nilai rata-rata sebesar 20,17. Bila kita bandingkan dengan total nilai hasil belajar yang ada yaitu sebesar 26 , maka nilai rata-rata hasil belajar matematika dapat dikonversi menjadi sebesar $=((20,17) / 26) * 100=77,57$. Dari hasil nilai tersebut maka untuk mengetahui tingkat serapan siswa dalam belajar matetmatika dapat menggunakan kriteria nilai angka dengan huruf seperti dibawah ini:

\begin{tabular}{|l|c|}
\hline RENTANG NILAI & GRADE \\
\hline $0-59$ & E \\
\hline $60-69$ & D \\
\hline $70-79$ & C \\
\hline $80-89$ & B \\
\hline $90-100$ & A \\
\hline
\end{tabular}

Maka dapat disimpulkan bahwa nilai 77,57 berada pada rentang grade $\mathrm{C}$ yaitu diantara $70-$ 79. Dengan demikian dapat kita simpulkan bahwa hasil belajar matematika siswa berada pada tingkat kategori “C” atau “Cukup”.

Kemudian untuk mengeatahui apakah nilai total tersebut terdistribusi secara normal atau tidak maka bisa kita lihat dari analisis Kurtosis dan Skewness. Berdasarkan hasil olah data maka didapatkan nilai analisis Kurtosis sebesar - 0,450 sementara nilai analisis Skewness sebesar 0,482 . Rentang nilai yang digunakan oleh analisis Kurtosis dan juga Skewness adalah antara 2,00 sampai dengan 2,00 maka dikatakan nilai tersebut terdistribusi secara normal, sehingga dari ketentuan nilai tersebut maka dapat disimpulkan bahwa nilai total untuk sikap belajar siswa telah terdistribusi secara normal karena untuk Kurtosis sebesar $-0,450>-2,00$ dan nilai Skewness sebesar $-0,482>-2,00$.

\section{Hubungan antara sikap siswa dengan hasil belajar matematika}

Setelah melakukan olah data dengan menggunakan SPSS (Statistical Package for the Social Sciences) versi 22, maka hubungan antara sikap siswa dengan hasil belajar matematika dapat digambarkan secara lengkap dibawah ini: 
Tabel 4.6: Statistik Sikap dan Hasil Belajar

\begin{tabular}{|l|c|r|r|}
\hline & Mean & Std. Deviation & \multicolumn{1}{c|}{ N } \\
\hline Total_Mtk & 20.1667 & 2.96047 & 30 \\
Total_Skp & 51.1667 & 9.59915 & 30 \\
\hline
\end{tabular}

Dari table di atas menunjukkan bahwa banyaknya siswa yang dijadikan sample sebanyak 30 orang. Nilai rata-rata untuk sikap belajar adalah sebesar 51,17 sementara nilai rata-rata untuk hasil belasar matematika adalah sebesar 20,17.

\section{Correlations}

\begin{tabular}{|c|c|c|c|}
\hline & & Total_Skp & Total_Mtk \\
\hline \multirow[t]{3}{*}{ Total_Skp } & Pearson Correlation & 1 & $.560^{* \prime}$ \\
\hline & Sig. (2-tailed) & & .001 \\
\hline & $N$ & 30 & 30 \\
\hline \multirow[t]{3}{*}{ Total_Mtk } & Pearson Correlation & $.560^{* *}$ & 1 \\
\hline & Sig. (2-tailed) & .001 & \\
\hline & $\mathrm{N}$ & 30 & 30 \\
\hline
\end{tabular}

Dari table di atas maka dapat dilihat bahwa sikap siswa berkorelasi (berhubungan) dengan hasil belajar siswa yang ditunjukkan dengan Sig (2-tailed) sebesar 0,001 $<0,05$. Korelasi tersebut bersifat positif yang ditujukkan oleh Pearson Correlation yang positif yaitu 0,560. Sementara untuk derajat keeratan korelasi atau hubungan antara sikap siswa terhadap hasil belajar adalah "Sedang" yang ditunjukkan oleh Pearson Correlation sebesar 0,560 yang berarti berada pada 0,41 s/d 0,60 yaitu derajat keeratan "Sedang". Berikut adalah tingkat derajat keeratan korelasi:

a. Nilai Pearson Corelation (R) berada diantara 0,00 s/d 0,20 maka tidak ada korelasi

b. Nilai Pearson Corelation (R) berada diantara 0,21 s/d 0,40 maka ada korelasi lemah

c. Nilai Pearson Corelation (R) berada diantara 0,41 s/d 0,60 maka ada korelasi sedang

d. Nilai Pearson Corelation (R) berada diantara 0,61 s/d 0,80 maka ada korelasi kuat

e. Nilai Pearson Corelation (R) berada diantara 0,81 s/d 1,00 maka ada korelasi sangat kuat

\section{Hubungan motivasi belajar siswa dengan hasil belajar matematika}

Setelah melakukan olah data dengan menggunakan SPSS (Statistical Package for the Social Sciences) versi 22, maka hubungan antara motivasi siswa dengan hasil belajar matematika dapat digambarkan secara lengkap dibawah ini:

Tabel 4.9: Statistik Motivasi dan Hasil Belajar

\begin{tabular}{|l|c|r|r|}
\hline & Mean & Std. Deviation & \multicolumn{1}{c|}{ N } \\
\hline Total_Mtk & 20.1667 & 2.96047 & 30 \\
Total_Mtv & 59.5000 & 7.71362 & 30 \\
\hline
\end{tabular}

Dari table di atas menunjukkan bahwa banyaknya siswa yang dijadikan sample sebanyak 30 orang. Nilai total rata-rata untuk motivasi belajar adalah sebesar 59,50 sementara nilai total rata-rata untuk hasil belasar matematika adalah sebesar 20,17. 


\section{Correlations}

\begin{tabular}{llr|r} 
& & Total_Mtv & Total_Mtk \\
\hline Total_Mtv & Pearson Correlation & 1 & -.138 \\
\cline { 2 - 4 } & Sig.(2-tailed) & & .467 \\
\cline { 2 - 4 } & $\mathrm{N}$ & 30 & 30 \\
\hline \multirow{2}{*}{ Total_Mtk } & Pearson Correlation & -.138 & 1 \\
\cline { 2 - 4 } & Sig.(2-tailed) & .467 & \\
\cline { 2 - 4 } & $\mathrm{N}$ & 30 & 30 \\
\hline
\end{tabular}

Dari table di atas maka dapat bahwa motivasi siswa tidak berkorelasi dengan hasil belajar siswa, hal ini ditunjukkan dengan nilai Sig (2-tailed) sebesar 0,467, dan karena 0,467>0,05 maka dapat disimpulkan bahwa motivasi siswa tidak berkorelasi terhadap hasil belajar siswa.

\section{Hubungan antara sikap dan motivasi belajar siswa dengan hasil belajar matematika}

Untuk mengetahui adanya hubungan antara variable sikap belajar (X1) dan motivasi belajar (X2) terhadap hasil belajar matematika (Y) siswa, maka kita dapat menganalisis dengan analisis regresi linear berganda. Dalam SPSS versi 22 kita bisa dapatkan hasil olah data sebagai berikut:

\begin{tabular}{|c|c|c|c|c|c|c|c|c|c|}
\hline \multicolumn{10}{|c|}{ Model Summary } \\
\hline \multirow[b]{2}{*}{ Model } & \multirow[b]{2}{*}{$\mathrm{R}$} & \multirow[b]{2}{*}{$R$ Square } & \multirow[b]{2}{*}{$\begin{array}{l}\text { Adjusted R } \\
\text { Square }\end{array}$} & \multirow[b]{2}{*}{$\begin{array}{l}\text { Std. Error of } \\
\text { the Estimate }\end{array}$} & \multicolumn{5}{|c|}{ Change Statistics } \\
\hline & & & & & $\begin{array}{c}\text { R Square } \\
\text { Change }\end{array}$ & F Change & df1 & df2 & $\begin{array}{l}\text { Sig. F } \\
\text { Change }\end{array}$ \\
\hline 1 & $.602^{\mathrm{a}}$ & .362 & 315 & 2.45038 & 362 & 7.665 & 2 & 27 & .002 \\
\hline
\end{tabular}

Dari hasil tabel di atas maka dapat disimpulkan bahwa secara simultan variabel sikap belajar dan motivasi belajar berkorelasi terhadap hasil belajar siswa, hal ini ditunjukkan dengan nilai Sig F change sebesar 0,002. Untuk dasar pengambilan keputusan adalah sebagai berikut:

a. Jika nilai Signifikansi F Change $<0,05$ maka berkorelasi.

b. Jika nilai Signifikansi F Change $>0,05$ maka tidak berkorelasi.

Berdasarkan dasar pengambilan keputusan maka nilai $0,002<0,05$ sehingga dapat disimpulkan bahwa sikap belajar dan motivasi belajar siswa secara simultan berkorelasi terhadap hasil belajar siswa. Selain itu juga dapat disimpulkan bahwa jenis korelasi antara sikap belajar dan motivasi belajar secara simultan terhadap hasil belajar adalah positif yang ditunjukkan dengan nilai $\mathrm{R}$ yang positif pula.Kemudian untuk mengetahui keeratan hubungan antara variabel-variabel $\mathrm{X}$ terhadap variabel $\mathrm{Y}$, maka dapat dilihat pada tabel bahwa $\mathrm{R}$ didapatkan sebesar 0,602, maka dapat disimpulkan bahwa derajat keeratan hubungan antara sikap belajar dan motivasi belajar secara simultan terhadap hasil belajar adalah berada diantara $0,40 \mathrm{~s} / \mathrm{d}$ 0,60 atau tingkatan positif.

\section{KESIMPULAN}

Berdasarkan hasil penelitian dan analisis data hasil penelitian dapat di tarik beberapa kesimpulan sebagai berikut :

1. Terdapat hubungan yang positif dan signifikan antara sikap siswa dengan hasil belajar matematika, mengandung arti bahwa semakin positif sikap siswa, maka semakin baik pula hasil belajar matematikanya, begitupun sebaliknya.

2. Terdapat hubungan positif dan signifikan antara motivasi belajar dengan hasil belajar 
matematika, mengandung arti bahwa semakin tinggi motivasi belajar, maka semakin baik pula hasil belajar matematikanya, begitupun sebaliknya, semakin rendah motivasi belajar maka semakin rendah hasil belajar matematikanya.

3. Terdapat hubungan positif dan signifikan antara sikap siswa dan motivasi belajar secara bersam-sama dengan hasil belajar matematika, mengandung arti bahwa semakin tinggi sikap siswa dan motivasi belajar, maka semakin baik pula hasil belajarnya.

Berdasarkan kesmipulan penelitian di atas, maka diajukan beberapa saran sebagai berikut :

1 Kepada siswa diharapkan memiliki sikap belajar yang positifdan motivasi belajar yang tinggi dari diri sendiri agar hasil belajar meningkat.

2 Kepada guru agar dapat menanamkan sikap belajar yang positif dan menumbuhkan motivasi belajar yang tinggi kepada siswa dalam upaya peningkatan hasil belajar matematik.

3 Kepala sekolah hendaknya meningkatkan pengawasan terhadap proses pembelajaran dan memfasilitasi siswa dan guru, melengkapi sarana dan prasarana belajar dalam upaya peningkatan hasil belajar matematika

4 Saran untuk peneliti lainnya:

a. Dengan keterbatasan penelitian ini, tentunya hasil penelitian ini tidaklah sempurna,sehingga di harapkan dapat menerima saran dan kritik yang membangun dari peneliti sebelumnya.

b. Bagi peneliti mengenai hasil belajar matematika selanjutnya di harapkan kiranya dapat di jadikan acuan untuk mengembangkan teori yang ada.

\section{DAFTAR PUSTAKA}

Angga, Dina Thalib, Raja. 2014. "Motivasi Belajar, Kemandirian Belajar dan Prestasi Belajar Mahasiswa Beasiswa Bidikmisi Di UPBJJ UT Bandung”. Jurnal Pendidikan Terbuka dan Jarak Jauh”, Volume 15, Nomor 2, September 2014.

Anwar, Z. 2012. Pelaksanaan Pembelajaran Matematika di Sekolah Dasar. Jurnal Penelitian Ilmu Pendidikan, 5(2), 24-32. Retrieved from https://journal.uny.ac.id/index.php/jpip/article/view/4747/4106.

Bastari, Elvina. 2019. Hubungan Motivasi Belajar dengan HAsil Belajar Peserta Didik pada Mata Pelajaran IPS Kelas IV SD Negeri 1 Sukabumi Indah Bandar Lampung Tahun 2018/2019. Skripsi. Lampung: UIN Raden Intan http://repository.radenintan.ac.id/5912/1/SKRIPSI\%20ELVINA\%20BASTARI.pdf

Dimyati dan Mudjiono. 2006. Belajar dan Pembelajaran. Jakarta: Rineka Cipta.

Hamalik, Oemar. 2011. Proses Belajar Mengajar. Jakarta: Bumi Aksara.

Karso, H. 2014. Pembelajaran Matematika di SD. Jakarta: Universitas Terbuka Ngalim Purwanto. 2006. Psikologi Pendidikan. Bandung:PT. Remaja Rosdakarya.

Rianda, Yoanna Nungki. 2016. Hubungan Motivasi Belajar dan Sikap Belajar Terhadap Hasil Belajar Matematika Pokok Bahasan Belah Ketupat dengan Menggunakan Model Pembelajaran Kooperatif Number Heads Together (NHT) pada Siswa Kelas VII B SMP Pangudi Luhur Moyudan Tahun Ajaran 2015/2016. Skripsi. Yogyakarta: Universitas Sanata Dharma. http://repository.usd.ac.id/6797/2/121414004_full.pdf

Rindra Listrianto, Hubungan Motivasi Belajar Dengan Hasil Belajar Matematika Siswa Kelas IV MIN 8 Bandar Lampung Tahun Ajaran 2016/2017, (Bandar Lampung: Skripsi Tarbiyah )

Sardiman, A. M. 2014. Interaksi dan Motivasi Belajar Mengajar. Jakarta: Raja Grafindo. 
Siregar, Eveline dan Nara, Hartini. 2010. Teori Belajar dan Pembelajaran. Bogor: Penerbit Ghalia Indonesia).

Slameto. 2015. Belajar dan Faktor-Faktor yang Mempengaruhinya. Jakarta: Rineka Cipta.

Sudjana, Nana. 2002. Dasar-dasar Proses Belajar Mengajar. Bandung: Sinar Baru Algensido Offset.

2017. Penilaian Hasil Proses Belajar Mengajar. Bandung: PT. Remaja Rosdakarya.

Syah, Muhibbin. 2006. Psikologi Belajar. Jakarta: PT Raja Grafindo Persada.

Walgito, Bimo. 2003. Psikologi Sosial: Suau Pengantar. Yogyakarta: CV. Andi Offset.

Wandini, R. R. \& Banurea, O, K. 2019. Pembelajaran Matematika untuk Calon Guru MI/SD. Medan: CV. Widya Puspita. 